\title{
South African
}

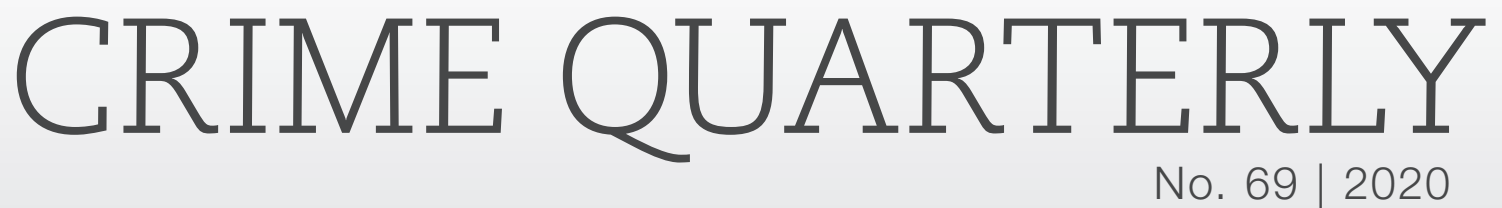

\section{Admission of guilt fine}

\section{A legal shortcut with delayed shock?}

\section{Hennie van As and Deon Erasmus ${ }^{1}$}

Hennie.vanas@mandela.ac.za

Deon.Erasmus@mandela.ac.za

http://dx.doi.org/10.17159/2413-3108/2020/i69a7444

A popular perception shared by peace officers and the public alike is that the payment of an admission of guilt fine finalises the judicial process and no criminal record will result. However, paying an admission of guilt fine in terms of section 56 of the Criminal Procedure Act means that the person is deemed to have been convicted and sentenced in a court of law. People who pay admission of guilt fines later discover with shock that they in fact have a criminal record, with severe consequences.

Often costly High Court applications will have to be instituted to set aside the conviction and sentence. Peace officers have a duty to inform a person of the consequences of paying an admission of guilt fine, but often do not do so and even abuse the admission of guilt system to finalise matters speedily. This article examines the consequences for a person who pays an admission of guilt fine. It further investigates whether there is a duty on Legal Aid South Africa to provide legal assistance in these matters and whether an administrative infringement process should be investigated.

In South African law, a person may acquire a criminal record in one of three ways: when entering a plea of guilty when prosecuted, upon conviction after a plea of not guilty, and when an admission of guilt fine (AGF) is paid. ${ }^{2}$ There are two ways in which a conviction can result from the payment of an AGF, namely section 57(1)(a) or (b) and section 57A(1) of the Criminal 
Procedure Act (CPA). ${ }^{3}$ The conviction is either as a consequence of a written notice issued by a peace officer in terms of section 56 of the CPA or as a result of a written notice issued by a public prosecutor in terms of section 57A(1) for an accused to appear in court, with the option of paying an AGF instead of appearing in court.

It is widely believed by peace officers and the public alike that if the police did not take a person's fingerprints upon conviction or when a fine is paid, no criminal record will result. ${ }^{4}$ This is not necessarily true. Fingerprints are not needed to record a conviction and the admission of guilt can be submitted by police to the criminal record centre. ${ }^{5}$ As will be illustrated, there are many people unaware that they have criminal records. ${ }^{6}$ When a fine is paid, the accused is considered correctly convicted under all statutory and common law offences. People opt to pay the fine to secure their release and avoid spending a night in a police cell, but do not realise that paying the AGF has severe consequences. ${ }^{7}$ For example, it could serve as the basis for terminating a lease, could disqualify someone from obtaining a visa for travel or emigration, or be grounds for instant dismissal if a person works in a financial institution. ${ }^{8}$

The result of the current admission of guilt system is that there is a large group of people who pay an AGF without knowing or fully understanding the consequences of their decisions. ${ }^{9}$ They rarely have access to legal advice and are often enticed to make these decisions, which they rue later.

This article examines the consequences for people who pay an AGF after receipt of a written notice to appear in court in terms of sections $57(1)(b)$ and 56(1) of the CPA. It further investigates whether there is a duty on Legal Aid South Africa to provide legal advice in these matters. We do not deal with an AGF paid after a summons ${ }^{10}$ was endorsed by the public prosecutor, ${ }^{11}$ or after appearing in court, but before entering a plea ${ }^{12}$ and fines imposed for traffic offences.

\section{The admission of guilt system}

Section 56(1) of the CPA provides:

If an accused is alleged to have committed an offence, and a peace officer on reasonable grounds believes that a magistrate's court, on convicting such accused of that offence, will not impose a fine exceeding the amount determined by the Minister of Justice from time to time by a notice in the Gazette, such peace officer must hand to the accused a written notice which shall [...] call upon the accused to appear at a place and on a date and at a time specified in the written notice to answer a charge of having committed the offence in question. ${ }^{13}$

It may also contain an endorsement in terms of section 57 that the accused may admit his guilt in respect of the offence and pay a stipulated fine without appearing in court. ${ }^{14}$ The notice must contain a certificate signed by the peace officer that he has handed the original to the accused and that he has explained its importance to the accused. ${ }^{15}$ The peace officer must forward a duplicate to the clerk of the court which has jurisdiction, ${ }^{16}$ as prima facie proof that it was issued and handed to the accused. ${ }^{17}$

Section 57(1)(b) provides that the accused may, without appearing in court, admit his guilt by paying the fine stipulated. Where a fine was paid, the money and notice must be forwarded to the clerk of the magistrate's court which has jurisdiction. As provided for in the Code for Clerks of the Criminal Court, ${ }^{18}$ the clerk completes the criminal record book for admissions of guilt, whereupon the accused is deemed to have been convicted and sentenced by the court in respect of the offence in question. ${ }^{19}$ 
This Code determines how clerks of the court must proceed when they receive AGFs up to the point that admission of guilt register is submitted to the responsible judicial officer, ${ }^{20}$ who must scrutinise the documents. ${ }^{21}$ If it appears to them that a conviction or sentence under subsection (6) is not in accordance with justice or the determination ${ }^{22}$ for the amounts set for an AGF, they may set aside the conviction and sentence and direct that the accused be prosecuted. ${ }^{23}$ Recent cases include $S v$ Perrang ${ }^{24}$ where the accused paid an AGF of R6 000 for possession of 223 crayfish $^{25}$; $S$ v Ajouhran ${ }^{26}$ where an AGF of R9 000 was paid for possession of 454 undersized crayfish $^{27}$ and $S v \operatorname{Simba}{ }^{28}$ where an AGF of R800 was paid for possession of cannabis. ${ }^{29}$ These matters were reviewed before the High Courts ${ }^{30}$ and in each case, the magistrate set aside the deemed conviction and sentence, and directed that the accused be prosecuted in the ordinary course. There are also instances in which the courts cautioned that the payment of an AGF was used as a 'nonchalant quick-fix method' to expedite and finalise criminal proceedings. ${ }^{31}$ The cases discussed below illustrate that matters falls through the cracks despite procedural safeguards.

\section{Those that fell through the cracks}

The advantages of paying an AGF seem obvious, but Curlewis warns that the practical implications are not always understood and could amount to 'seeing only the tip of the iceberg'. ${ }^{32}$ Some are of the opinion that, in practical terms, it is 'unlikely that the payment of an AGF will cause a person much trouble in the future, as it seems from anecdotal accounts from persons working at the local authorities or police stations that such convictions are not entered into the SAP 69 register, or if they are, they do not appear on a criminal record clearance check.' ${ }^{33}$ However, this practice has indeed resulted in trouble for some.

\section{S v Parsons ${ }^{34}$}

The accused was convinced by the investigating officer to pay an AGF for 'disturbing the peace'. She stated that 'I was issued with the fine but never was it explained to me that I would receive a criminal record. Had this been explained to me ... I would definitely have appeared ...' She was deemed to have been correctly convicted. ${ }^{35}$

In determining whether the deemed conviction should be set aside, the court referred to the guidelines set out in $S$ v Cedras: ${ }^{36}$

(a) Are there considerations of equity and fair dealing that compel the court to intervene to prevent a probable failure of justice?

(b) Has good cause been shown for mistakenly or erroneously admitting guilt?

(c) Are there indications that, were the charge to go to trial, she would have a probable or arguable defence?

The police officer misrepresented the facts by stating that payment of the fine would finalise the matter. ${ }^{37}$ The court described such actions as 'dangerously attractive' to an unsuspecting member of the public, ${ }^{38}$ and held that drawing a person's attention to the fact that a conviction shall be recorded is not only fair, but constitutionally obligatory. ${ }^{39}$

The section 56 notice issued at the time did not contain any warning that payment of a fine translated into a conviction. The police officer should have warned the accused about the possible conviction record. ${ }^{40}$ The court was satisfied that the accused was wrongly led to admit guilt and wrongly convicted and the conviction and sentence were set aside.

\section{Tong $v$ The State ${ }^{41}$}

The applicant was arrested in 2008 for possession of cannabis in contravention of section 4(b) of the Drugs and Drugs Dependency Act $^{42}$ after he was found in a street near a packet containing cannabis (which was 
presumed to be his). The police informed him that he could facilitate his release by paying an AGF. The appellant's father paid an AGF of R200 and the applicant was asked to sign various documents. He was not offered legal representation and the police did not explain the process to him. He was not consulted about the AGF, did not agree to pay the fine and was not informed that an AGF had been paid by his father. He was asked for an address and assumed that he would receive a notice to appear in court, but never did.

In 2011 he applied for a work visa to teach abroad and was surprised to find that he had a criminal record, which disqualified him from any teaching placement or travel abroad. Moreover, the records of his case at the Magistrate's Court had been destroyed. ${ }^{43}$ Tong averred that he was severely prejudiced as he was not afforded the opportunity to defend himself in court and that he would have elected to do so.

The difficulty with the case was that there were allegations that the police did not explain the applicant his rights and the implications paying an AGF before the fine was paid, with no evidence to the contrary. ${ }^{44}$ The court was of the opinion that the payment of an AGF is premised on the fact that the payer of the fine would have been fully appraised of his rights and the consequences before electing to do so. ${ }^{45}$ The exercise of such a choice amounts to the waiver of several procedural rights, which an accused would enjoy at a trial, such as the right to be sentenced only upon proof beyond reasonable doubt that he committed the alleged offence. A number of constitutional rights are also infringed upon, namely the rights to dignity, freedom, security of the person, employment, privacy, freedom of movement and residence, as well as the right to a fair trial.

The court referred to NGJ Trading Stores (Pty) Ltd $v$ Guerreiro ${ }^{46}$ which held that payment of an AGF amounted to a conviction serious enough to allow the termination of a lease, where the lease stipulates that being convicted of any offence is grounds for cancelling the agreement. Despite these risks, the court also described the AGF system as an indispensable component of the criminal justice system, which lessens the burden on the already overloaded system. ${ }^{47}$

What makes matters worse in the Tong case was the fact that the police docket could not be traced, ${ }^{48}$ with the result that the Director of Public Prosecutions could not properly respond to the applicant's allegations that the police did not explain his rights. The applicant also submitted that the AGF was used by the police as a bargaining tool to affect his release from custody. In effect, he was not given the choice to pay a fine before a certain future date. ${ }^{49}$ The police effectively enforced payment. The court found this unlawful, especially as the applicant had not effectively waived his choice to consider to pay at a later date or to contest the matter. ${ }^{50}$

\section{S v Rademeyer ${ }^{51}$}

Rademeyer was accused of shoplifting and was served with a document called 'Notice of Rights in Terms of the Constitution' at the police station. ${ }^{52}$ The SAPS 14A details the reason that the accused is being detained and informs them that they have the 'right to consult with a legal practitioner of your choice or should you so prefer, to apply to the Legal Aid Board to be provided by the State with the services of a legal practitioner [...]'

In the middle of the SAPS 14A, is a portion called 'Certificate by Detainee', which states:

I, (name of detainee) hereby certify that I have been informed in English of my rights in terms of the Constitution as set out above by (name of person who informed the detainee) and that I understand the contents thereof.

It was signed by the detainee and a person who explained her rights to her. 
Rademeyer was handed a section 56 notice to appear in court with the SAPS 14A. The notice contained a warning that an ' $[A] d m i s s i o n$ of guilt fine of R500 may be accepted.' She was notified that she would have to appear at court on 9 September 2014. Instead of attending court, she opted, without the benefit of legal advice, to pay the AGF.

She subsequently sought a police clearance certificate, which showed that she was convicted of theft and fined R500. According to her court documents ' $[$ T] his revelation was unexpected. She was stunned, confused and frustrated. ${ }^{53}$ Her affidavit stated that:

At the police station it was not explained to me that signing an admission of guilt will be held against me for a 10 year period. I was unaware of the consequences by signing the admission of guilt. I never received nor signed a summons. The option of going to court was not even mentioned to me by the police station.

The court concurred with the judgment in the Tong case that section 57 of the CPA imposes no duty on a police officer to warn an accused of the full consequences of paying an AGF. ${ }^{54}$ Therefore, in the absence of clear legislative prescriptions, the courts require law enforcement officers to warn accused of the consequences of paying an AGF. In Tong ${ }^{55}$ the court stated that:

As such, the accused must be informed that he or she will be deemed to have been sentenced and convicted by the court with jurisdiction in respect of the offence in question. It must be furthermore explained to an accused that, if it is indeed the case, such conviction will appear on the accused's criminal record. A police officer must further inform the accused that, as a consequence of paying an AGF, an accused would be waiving the right to be sentenced only upon proof beyond reasonable doubt that one is guilty of the commission of the offence, the right to contest the allegations in open court, the right to confront one's accusers, the right to call witnesses and the right to legal representation. A police officer must state in a certificate referred to in s 56(1)(d) of the Act contained in a written notice, that he/she has indeed warned the accused in the above manner.

Rademeyer averred that it was never explained to her that paying the fine would result in a criminal conviction, but the court held that there was no duty on a police officer to do so. ${ }^{56}$ The judge equated it with the situation where a judge or magistrate does not have to warn an accused in advance that conviction will result in a criminal record. The court argued that certificate warranting that the police officer has explained the full import of the processes may be desirable, but its absence does not imply that the accused's right to a fair trial has been trampled. ${ }^{57}$

The court was of the opinion that the law should be developed to incorporate a warning into the section 56 notice that payment of an AGF translates into a conviction. The absence of such warning is 'not fair to unsuspecting members of the public.' 58 Based on the test developed in Cedras the court confirmed the original outcome.

\section{S v Madhinha ${ }^{59}$}

In 2010 Madhinha allegedly slapped a fellow vendor. He was detained, fingerprinted and handed a written notice, which included an endorsement that he may admit guilt. He paid the R500 fine and was released. In 2018 he applied to join Uber as a driver and required a police clearance certificate. This revealed that he had a criminal record and he applied to have the conviction and sentence set aside. $\mathrm{He}$ alleged that he was led to believe that the only option to be released from custody was 
to pay a fine immediately and that payment was accordingly not made freely and voluntarily. $\mathrm{He}$ also averred that his constitutional rights were not explained at any stage.

The paperwork relating to Madhinha's AGF had been entered in the criminal record book kept for admissions of guilt. ${ }^{60} \mathrm{~A}$ few days later, a magistrate 'examined' the documents ${ }^{61}$ and, having done so, set aside neither the conviction nor the sentence. This cleared the way for the police to enter his name and details in their criminal record system.

Madhinha approached the court, raising the question that has long troubled many people: when someone pays an AGF what is the precise status of that transaction? Madhinha said the conviction and sentence resulting from paying the fine should be set aside as it was 'not in accordance with justice'. He accepted that if the conviction and sentence were set aside, he might still be prosecuted in relation to the original matter.

The court expressed doubt whether the result of the payment of a fine issued in term of section 56 is a conviction as envisaged in section 271 of the CPA (a previous conviction by a court of law). The court was also doubtful whether such section 56(7) conviction should be entered and appear as a previous conviction on a person's criminal record (in terms of section 271 of the Act). ${ }^{62}$

The court ruled that the level of court, and the fact that the fine represents $8.33 \%$ of the limit of jurisdiction for magistrate's courts, indicates that the method is meant primarily for less serious offences. ${ }^{63}$ According to the court, a conviction and sentence in terms of section 57(6) is not a verdict, but an automatic consequence of an administrative act performed by a member of the court's support services. ${ }^{64}$

In the court's view, the section 57 mechanism is intended to settle trivial disputes between the state and accused persons where 'neither party wish to go through a long trial procedure and both are willing to bring their dispute to a quick end'. ${ }^{65}$ It is regarded as a waiver by both parties - the state waives the offences upon payment of an amount and the accused waives his right to have his case proved beyond reasonable doubt. It is not an unequivocal admission of guilt, primarily because it is not required that the facts of the offence be set out, or that it be confirmed and reduced to writing in the presence of a magistrate or peace officer. ${ }^{66}$

The court pointed to two cases from $2013,{ }^{67}$ where the accused had also said they did not know that payment of a fine would lead to a criminal record, and where the High Court had appeared to 'accept, without deciding' that a section 57 (6) conviction had the required status to result in a permanent record, which was the narrow issue raised by Madhinha.

According to the court the appropriate way to deal with his application was to set the proceedings aside and let the state prosecute if it wished to prove his guilt. 68 The court recommended that the National Commissioner of Police should require SAPS members to submit a monthly written record of detentions where an AGF is used, including the reasons for the fine. The court was of the view that:

The record should show why it was necessary to arrest someone before giving them notice of the option of an AGF. A policy should also be drafted that would address the criticism 'that the SAPS use arrest and detention to force vulnerable members of society who fear being locked up, to admit guilt on petty crimes using arrest and the threat of continued detention.

The court held that a conviction and sentence following an entry into the admission of guilt record book by the clerk of the criminal court in the magistrate's court 'is not a conviction whose 
record is permanent' and that the conviction and sentence of Madhinha under section 57(6) should be set aside. ${ }^{69}$

\section{Mong v Director of Public Prosecutions $^{70}$}

The applicant was arrested for possession of cannabis. He denied that it was ever in his possession. Although he paid an AGF, Mong denied admitting that the cannabis was his and said that he was unaware that paying the fine would result in a criminal record. He sought an order directing that the fine be expunged from the register of his previous convictions. Section 57(7) of the CPA requires a judicial officer presiding at a court to examine the documents and confirm the conviction and/or sentence before it is entered into the Criminal Record Book for admissions of guilt. Mong argued that these provisions were not complied with, and that he was not told of the consequences that would flow from the payment of the fine while he was still under arrest.

The court was very critical of the decision in Madhinha, arguing that section 57(6) of the CPA seeks to 'facilitate the recording of the particulars of summons or notice in the criminal record book for admissions of guilt, which would be deemed to be a conviction and sentence by a court. ${ }^{71}$ Although section 57(6) results in a conviction and sentence, which is normally the function of a magistrate or judicial officer, the fact that the AGF is recorded by the clerk of the court does not confer on them the powers of a magistrate or judicial officer to convict or sentence. The court also found Madhinha to be at odds with NGJ Trading Stores, ${ }^{72}$ which is still binding authority. The court ordered that the previous conviction based on the entry in the Criminal Record Book be removed and that the R500 AGF be paid back to Mong. The DPP could decide whether to prosecute Mong afresh. ${ }^{73}$

\section{Duties of peace officers regarding AGFs}

From these cases it appears that the payment of an AGF is often used as a bargaining tool by police officers to affect the release of a person from custody. ${ }^{74}$ While it cannot be disputed that an AGF is an important component of the criminal justice system and that it eases the burden on an already overloaded criminal justice system, ${ }^{75}$ it is premised on the fact that an accused is fully appraised of his or her rights and the consequences of their choice. ${ }^{76}$

The court held in Tong ${ }^{77}$ that a peace officer must warn an accused of certain consequences of paying an AGF, including that:

- he/she will be deemed to have been convicted and sentenced by a court;

- such conviction will appear on the accused's criminal record; and

- the accused will be waiving the right to be sentenced only upon proof beyond reasonable doubt that he/she is guilty of the commission of the offence, the right to contest allegations in open court, the right to confront one's accusers, the right to call witnesses and the right to legal representation.

As a result of this ruling the J534 form (written notice to appear in court in terms of section 56 of the CPA) has been amended to include the following information:

\section{ADMISSION OF GUILT UNDER SECTION 57 OF ACT NO 51 OF 1977}

I hereby acknowledge that I am guilty of the offence(s) set out in this notice and they, by paying the admission of guilt, I will be deemed to have been convicted in Court of the offence(s) (without having appeared in Court, having had the benefit of facing my accuser, having had legal representation or having exercised by right to call a witness in open Court) and 
that the conviction may be recorded as a previous conviction against my name and may appear on my criminal record.

This is all well and good, but, in reality, most South Africans see criminal trials as a looming terror to be avoided as far as possible, resulting in the payment of AGFs without considering the possible consequences of the acknowledgement in the form $\mathrm{J} 534 .^{78}$

\section{Alternatives to AGF}

Diversion is available to first time offenders who freely admit their guilt before the commencement of a criminal trial. The most common offences for which diversion may be considered include theft or attempted theft, shoplifting, assault and possession of narcotics. ${ }^{79}$ Diversion for adults is usually initiated by an accused's legal representative in the form of written representations to prosecutors or at the initiative of prosecutors. ${ }^{80}$ In instances where AGFs are paid, however, the recipient of the J534 notice effectively waives the right to legal representation and may therefore be unaware that diversion may be an option.

Informal mediation is a process whereby a prosecutor acts as a mediator between the victim and the offender and resolves the conflict that resulted in the criminal case. The matter is then withdrawn. ${ }^{81}$ In many instances where AGFs are paid, the crimes are 'victimless' (e.g. fishing without a licence, being in possession of abalone without a permit, possessing undersized mussel or crayfish, and so on), and mediation is therefore not an option.

A third possibility is to use administrative processes in place for specific types of offences, such as the new infringement system introduced by the Administrative Adjudication of Road Traffic Offences Act. ${ }^{82}$ Under this system minor traffic offences, referred to as infringements, result in administrative fines.
If the infringer pays the fine, demerit points are allocated, which can eventually result in the suspension of their driver's licence for a specified period, but does not result in a criminal record. ${ }^{83} \mathrm{~A}$ person can also decide to have the infringement adjudicated in court and section 54 of the CPA then applies. A conviction does not result in a criminal record..$^{84}$

Lastly section 341 of the CPA deals with the compounding of certain minor offences. It makes provision for the issuing of a written notification alleging that a person has committed a minor offence, as well as the amount which a court would impose as a fine. If the person pays that amount within 30 days in the prescribed manner, they will not be prosecuted for the offence, and no criminal record is incurred. ${ }^{85}$

\section{The duty to provide legal aid}

In South Africa, the provision of criminal legal aid is an obligation imposed by the human rights chapter of the Constitution. ${ }^{86}$ Legal Aid South Africa was established in terms of the Legal Aid South Africa Act ${ }^{87}$ to ensure compliance with international guidelines and the Constitution $^{88}$ by rendering or making available legal aid and legal advice, providing legal representation at state expense and providing education and information concerning legal rights and obligations. ${ }^{89}$

Regulation 3 of the Legal Aid Regulations (the Regulations) $)^{90}$ provides that Legal Aid South Africa may grant legal aid to a sentenced or detained person or an accused person in a criminal trial, provided that substantial injustice might occur if that person cannot afford legal representation and the possibility that he or she might be imprisoned exists. ${ }^{91}$ In assessing an application for legal aid by an applicant who is charged in the district magistrate's court with an offence that is not listed, ${ }^{92}$ legal aid may be granted after consideration of the complexity of the case in law and in fact, including the 
imposing of an appropriate sentence, the applicant's ability to represent himself, and the gravity of the case. ${ }^{93}$

Regulation 27 of the Regulations contains the qualification criteria and means test. If an applicant exceeds the means test, ${ }^{94}$ Legal Aid has the discretion to authorise fully subsidise their legal aid, can provide partial legal aid, or they can require that the applicant contribute to the cost. ${ }^{95}$ In assessing whether partial legal aid should be provided, Legal Aid must consider whether the applicant will suffer substantial injustice if legal aid is not provided, and can afford the cost of his or her own legal representation. ${ }^{96}$

As far as 'substantial injustice' is concerned, $S v$ Bhengu ${ }^{97}$ ruled that each case will have to be decided on its own merit. The Constitution ${ }^{98}$ also provides that every accused, detained and sentenced person has the right, where substantial injustice would otherwise result, to be provided with legal representation at State expense. ${ }^{99}$

It is clear from the case law discussed above that people who acquire a criminal record by paying an AGF might not have done so if they had legal advice. Legal Aid should assist people attempting to have their deemed conviction (as a result of paying an AGF) set aside if the criteria for such assistance are met and their application has sufficient merit. Legal Aid should also present educational and information sessions or distribute pamphlets informing the public about the consequences of paying an AGF.

\section{Conclusion}

People often opt to pay an AGF to secure their release from custody, to prevent a court appearance, or because they believe it will finalise the matter without the risk of incurring a criminal record. They are unaware that they will be deemed to have been correctly convicted and that such a conviction holds for all statutory and common law offences. It is costly to bring a High Court application to set aside a conviction, and there is consolation in the fact that the conviction automatically falls away after 10 years. ${ }^{100}$

Legal Aid should implement a system to fill the cracks to prevent serious injustice and possible adverse consequences resulting from the payment of an AGF. Information should be disseminated on the consequences of paying such fines as part of Legal Aid's community outreach programmes, which form part of its annual performance plan. ${ }^{101}$ Furthermore, there should be an expansion of the administrative processes for addressing minor offences. Such a process could include a confirmation of guilt phase that takes place before a magistrate delegated to oversee AGFs where the magistrate explains their rights to accused and confirms that they understand the consequences of paying such fines. The South African admission of guilt system should not be seen as a nonchalant 'quick fix'.

To comment on this article visit

http://www.issafrica.org/sacq.php

\section{Notes}

Hennie van As: https://orcid.org/0000-0002-5288-5344. Deon Erasmus: https://orcid.org/0000-0002-6070-7396.

1 Hennie Van As is a Professor in the Department of Public Law and Director of the FishFORCE Academy at Nelson Mandela University, One Ocean Hub Co-investigator with funding from the United Kingdom Research and Innovation (UKRI) Global Challenges Research Fund (GCRF) (Grant Ref: NE/S008950/1) and Honorary Senior Fellow in the Australian National Centre for Ocean Resources and Security (ANCORS) at the University of Wollongong, Australia. Deon Erasmus is a Professor and Head of the Department of Criminal and Procedureal Law at Nelson Mandela University.

2 NGJ Trading Stores (Pty) Ltd v Guerreiro 1974 (4) SA 738 (A), 476.

3 Criminal Procedure Act 1997 (Act 51 of 1977).

4 As far back as 2002 the South African Law Commission found that it is 'generally accepted that accused persons frequently select this option [to pay an AGF] in order to avoid having to contest a petty charge, rather than because they consider themselves guilty of an offence.' South African Law Commission, Project 73, Sixth Interim Report on 
Simplification of Criminal Procedure, August 2002, par 2.14, https://cisp.cachefly.net/assets/articles/attachments/00329_ salcsixthcrimprocedure.pdf (accessed on 22 May 2020).

5 S Regchand, Lockdown fine means a criminal record, 22 April 2020, www.news24.com/SouthAfrica/News/lockdown-finemeans-a-criminal-record-20200421 (accessed 21 May 2020).

6 As recently as the end of April 2020, the public was warned not to risk breaking the lockdown regulations as they could end up with a criminal record. See Regchand, Lockdown fine means a criminal record.

7 The impact of criminal records from AGFs has been recognised by the legislature and the courts alike. Section 271A-E of the CPA introduced the expungement of criminal records and the courts have held that "[a] criminal record is an impediment to opportunities such as employment, travel and many other areas of life." (S v Gilgannon [2013] ZAGPJHC266). Also see Tatham Wilkes, What are the consequences of paying an Admission of guilt fine?, 6 April 2018, www.tathamwilkes.co.za/NewsResources/NewsArticle. aspx?ArticleID=2384 (accessed 19 April 2019); Careers24, What it really means to find work with a criminal record in SA, undated, https://careeradvice.careers24.com/career-advice/ money/what-it-really-means-to-find-work-with-a-criminalrecord-in-sa-20170810 (accessed 23 May 2020).

8 A Serrao, Signing 'guilt fines' can be costly, 24 April 2013 https://www.iol.co.za/news/signing-guilt-fines-can-becostly-1505580 (accessed 1 April 2019). Also see M Slabbert and DJ Boome, Reformation from Criminal to Lawyer: Is such Redemption Possible?, PER, 2014 17(4) 44 that argues that although the 'fit and proper' requirement set for the admission of advocates and attorneys in terms of the Section 3 of the Admission of Advocates Act 74 of 1964 and section 15 of the Attorneys Act 53 of 1979 does not refer to previous convictions specifically, admission applications by persons with such convictions may succeed only in exceptional circumstances.

9 See Careers24, What it really means to find work with a criminal record in SA, undated, https://careeradvice. careers24.com/career-advice/money/what-it-really-means-tofind-work-with-a-criminal-record-in-sa-20170810 (accessed 23 May 2020) for examples.

10 CPA, section 54.

11 Ibid., section 57(1)(a).

12 Ibid., section 57A.

13 Ibid., section 56(1)(b).

14 Ibid., section 56(1)(c).

15 Ibid., section 56(1)(d).

16 Ibid., section 56(3).

17 Ibid., section 56(4).

18 Department of Justice and Constitutional Development, Codified instructions: code - clerks of the criminal court, chapter 6.

19 CPA section 57(6).

20 Codified instructions, paras 72 and 73.

21 CPA section 57(7).

22 See also $S$ v Karan unreported case no. 18808 (WCC).

23 CPA section 57(7). An accused can be refunded where the amount of the fine exceeds the amount determined by relevant magistrate.
24 S v Perrang unreported case no. A850/2017 (WCC).

25 The accused was found guilty under regulation 44(1)(a) of the Marine Living Resources Act 1998 (Act 18 of 1998).

26 S v Ajouran unreported case no. A2800/2017 (WCC).

27 The accused was found guilty under regulation 51(1) of the Marine Living Resources Act.

28 S v Simba unreported case no. A2241/17 (WCC).

29 Drugs and Trafficking Act 1992 (Act 40 of 1992), section 4(b).

30 The review related to the power of a judicial officer presiding at a magistrate's court to set aside a conviction and sentence in terms of section 57(7) of the CPA. The control prosecutor contended that the magistrate was not entitled to do so.

31 L Curlewis, Sugar-coating guilt: Admission of guilt fines - no easy fix, De Rebus, 540, 2014, 24.

32 Ibid., 25.

33 R Marais, Are you a convict? Admission of guilt fines and your criminal record, 1 September 2014, www.linkedin. com/pulse/20140901162245-89407255-are-you-a-convictadmission-of-guilt-fines-and-your-criminal-record (accessed on 16 April 2019).

34 S v Parsons unreported case no. C2791423 (WCC).).

35 Ibid., para 3.

36 S v Cedras 1999 (2) SA 530 (C) at 532.

37 Parsons para 4.

38 Ibid., para 5.

39 lbid.

40 Ibid., para 6.

41 Tong $v$ S unreported case no. 1287/2012 (WCC).

42 Drugs and Drugs Dependency Act (Act 140 of 1992).

43 Tong para 5.

44 Ibid., para 10.

45 Ibid., para 14.

461974 (4) SA 738 (A).

47 Tong, para 23.

48 Ibid., para 11.

49

50

51 S v Rademeyer Case No 272/16 (G).

52 Issued in terms of section 35 of the Constitution.

53 Rademeyer, para 6.

54 lbid., para 11.

55 Ibid., para 25.

56 Ibid., para 13.

57 lbid., para 18.

58 Ibid

59 S v Madhinha Review 18617 in the Western Cape High Court. Judgment delivered 7 December 2018.

60 Admission of guilt registers are destroyed after a year, unlike the criminal record books which are never destroyed.

61 Section 57(7) of the CPA requires a judicial officer to examine the AGF documents to detect any problems and to determine whether the conviction and sentence by operation of law is in accordance with justice. 
62 Madhinha, para 5.

63 Ibid., para 11 and 13.

64 Ibid., para 15.

65 Ibid., para 17.

66 CPA, section 271.

67 Parsons and Tong.

68 The strength of the case was never tested and a magistrate never found him guilty, or sentenced him.

69 See C Rickard, Admission of guilt - Permanent criminal record or not?, 17 December 2018, www.golegal.co.za/ admission-guilt-payment/ (accessed 19 April 2019).

70 Mong v Director of Public Prosecutions [2019] 4 All SA 447 (WCC).

71 Ibid., para 60.

72 Ibid.

73 ibid., para 86

74 Curlewis, Sugar-coating guilt, 25.

75 Tong, para 23

76 Ibid., para 14.

77 Ibid., para 25.

78 Schüler Heerschop Pienaar Attorneys, Diversion: The role of diversion in South African Law' www.shplaw.co.za/index. php/blog/22-diversion-the-role-of-diversion-in-south-africanlaw (accessed 16 April 2019).

79 Diversion in terms of the Child Justice Act 2008 (Act 75 of 2008) is not included in this discussion.

80 Schüler Heerschop Pienaar Attorneys, Diversion, 2.

81 National Prosecuting Authority (2011) Annual Report 2010/11, 147

82 The Administrative Adjudication of Road Traffic Offences Act, 1998 (Act 46 of 1998), amended by the Administrative Adjudication of Road Traffic Offences Amendment Act 2019 (Act 4 of 2019).

$83 \mathrm{H}$ Horn, Contesting traffic fines in SA: What are your rights?, wheels24, 13 February 2018, www.wheels24.co.za/News/ Guides_and_Lists/contesting-traffic-fines-in-sa-what-areyour-rights-20180213 (accessed 14 September 2019).
84 Ibid.

85 Ibid.

86 Constitution of the Republic of South Africa 2000 (Act 200 of 1993), chapter 2.

87 Legal Aid South Africa Act 2014 (Act 39 of 2014).

88 The right to a fair hearing, the right to equality before the law, the right of detained persons to choose and consult with legal practitioners, as well as the right to have legal practitioners assigned by the state and at state expense if substantial injustice would otherwise result. Accused persons are afforded the right to choose, and to be represented by a legal practitioner, to be informed of this right promptly, and to have a legal practitioner assigned to them by the state and at state expense, if substantial injustice would otherwise result.

89 Legal Aid South Africa Act.

90 Ibid and Regulations. GN R.745 GG 41005 of 26 July 2017.

91 In terms of regulation 3(2), a legal aid applicant who is charged in the High Court of South Africa or a Magistrate's Court for a regional division may be granted legal aid without any further enquiry into the nature and seriousness of the charge: Provided that such applicant is unable to afford the cost of his or her own legal representation that would sustain the anticipated duration of trial.

92 Regulation 3 (3)-(6).

93 Ibid., 3(7).

94 Ibid., 30.

95 Ibid., 31

96 Ibid., 31(2).

97 S v Bhengu [2010] ZAKZPHC 69 (1 October 2010).

98 Constitution, section 35(2)-(3).

99 Bhengu, para 14.

100 CPA, section 271A.

101 Legal Aid South Africa Report (2018) 29. 